\title{
TRENDS IN POTENTIAL ACCESSIBILITY TO AIRPORTS IN POLAND (AAI INDICATOR)
}

\author{
Piotr Rosik, Tomasz Komornicki, Sławomir Goliszek, Marcin Stępniak, Wojciech Pomianowski \\ Institute Geography and Spatial Organization \\ Polish Academy of Sciences \\ Twarda 51/55, 00-818 Warsaw: Poland \\ rosik@twarda.pan.pl,t.komo@twarda.pan.pl,sgoliszek@twarda.pan.pl,stepniak@twarda.pan.pl, \\ wpo@twarda.pan.pl
}

\begin{abstract}
Correct evaluation of transport investments financed under different operational programmes requires comprehensive analysis of the influence of those investments on transport accessibility changes. Accessibility changes concern multiple transport modes simultaneously (among others, road, railway, air and inland water transports). From this viewpoint, the factor of key importance is using a synthetic accessibility indicator in a multimodal approach as well as modal indicators, including Air Accessibility Indicator (AAI). In this paper air accessibility to airports was assumed to result on the one hand from the time of travel to all airports in the country, and on the other hand to depend on the airport capacity. All major investments carried out at airports and aimed at increasing the capacity of terminals were taken into consideration. Attractiveness of an airport was assumed to be analogous to its capacity. We use potential accessibility indicator. On each spatial level of the analysis below the national one, i.e. from the commune level through the voivodeship level up to the macro-region level, accessibility analysis is prepared based on all routes between an arbitrary pair of communes in Poland (matrix layout). We focus on the calculation of accessibility indicators at the municipal level.

Poland is slowly entering the development phase where some regions become saturated with modern transport infrastructure (road and air infrastructure in particular). By percentage, Eastern Poland benefited the most from air investments (over threefold AAI indicator increase), including in particular the Lublin and Podlaskie Voivodeships, primarily as a result of opening new airports in Lublin and Modlin.In conclusion, the conducted research confirms the thesis that improvement of accessibility in air transport may be achieved both by erecting or modernising airport infrastructure (new structures, capacity increase) and by developing land transport.
\end{abstract}

Keywords: potential accessibility, airports, capacity, accessibility monitoring.

\section{Introduction}

Compared to other Central and Eastern European countries, Poland suffered an exceptionally long break in implementing large transport investments. Starting around 1980, it continued de facto until the time of the country's accession to the European Union. During those 25 years, few new routes were created. In these conditions, emergence of the European Union support for major new undertakings (starting with the pre-accession ISPA programme) resulted in fast, though sometimes chaotic, intensification of investment activities. In the pre-accession period and during the first financial EU perspective (2004-2006), the country managed to implement just part of the initials 
plans. The years after 2004 brought an abrupt increase in numbers of passengers being serviced at many airports, in particular Krakow Balice and Katowice-Pyrzowice Airports, these also being the locations at which the roles won for themselves by "cheap airlines" were greatest. More about airports development in the geographic aspect of view, see also: Komornicki and Śleszyński (2011), Kopeć (2004), Pijet-Migoń (2007), Trzepacz (2007) and Taylor and Ciechański (2016).

At the onset of the second post-accession financial perspective (2007-2013), the authorities started paying attention to the need for clear specification of the goals of the individual investment projects. In 2007-2013, Poland started forming a network of fast traffic roads (by which we understand here both motorways and expressways), whose layout started (especially in western Poland) to gain the first features of cohesion. Less spectacular successes were achieved in developing the railway network. Until 2006, large transport investments were implemented centrally under the Operational Programme Transport. In the 2007-2013 perspective, the greatest actions were taken under the Operational Programme Infrastructure and Environment. At the same time, other transport investments were implemented with help of Regional Operational Programmes (16 voivodeships) and the Operational Programme Development of Eastern Poland. Smaller tasks in the borderlands were also supported from the European Territorial Cooperation funds.

Poland was, and still is, one of the greatest beneficiaries of structural aid, both in general and in transport. Just in the 2007-2013 perspective, the total value of transport projects exceeded PLN $99 \mathrm{M}$, with most of the money allocated to road investments. Under both financial perspectives, European Union funds were used to build a few sections of a latitudinal trunk road joining the German and Ukrainian borders through Wrocław and Kraków (A4 motorway). The central fragment of the Berlin-Warsaw motorway (A2 motorway) was also built, as well as a few fragments of the Gdańsk-Katowice-Czech border (Vienna) route (A1 motorway). In addition, a few express roads were built (among others, Łódź-Wrocław).

A specific feature of European Union funds utilization in the transport sector in Poland was a considerable share of agglomeration projects (among others, the underground in Warsaw, new tram lines, intra-urban road routes), port projects (facilities in Gdańsk, Gdynia, Szczecin and Świnoujście), and, last but not least, expansion of almost all airports operating in the country, as well as construction and launch of three new airports for regular flights (in Modlin, Lublin and Szymany).

Infrastructural investments were (especially during the first financial perspective) rather dispersed. Despite the initial modal balance, in the end decisively larger funds were used in road transport. Due to the very bad initial condition and enormous investment needs, neither the road nor the railway system were closed at the end of the perspective (2007-2013). As a result, the objectives were not achieved to the extent achieved e.g. in Hungary, the Czech Republic and Slovenia. This necessitated continuation of broadly planned actions during the present financial perspective (20142020). Compared to the preceding ones, it is (in line with European Commission's recommendations) oriented more at railway infrastructure. Investments in air transport are totally ruled out (except those connected with security improvement). A specific framework has also been imposed on the individual operational programmes. New financial instruments have emerged (among others, CEF). At present, part of the subsequent investments are already underway. Poland is at the infrastructure development stage which already allows for a comprehensive ex post evaluation of the completed tasks, and at the same time generates the need for a precise indication of new priorities (ex ante evaluation).

Correct evaluation of transport investments financed under different operational programmes (two national ones: Operational Programme Infrastructure and Environment and Operational Pro- 
gramme Development of Eastern Poland/Eastern Poland, and 16 Regional Operational Programmes) requires comprehensive analysis of the influence of those investments on transport accessibility changes (Komornicki et al. 2013). Accessibility changes concern multiple transport modes simultaneously (among others, road, railway, air and inland water transports). From this viewpoint, the factor of key importance is using a synthetic accessibility indicator in a multimodal approach as well as modal indicators, including Air Accessibility Indicator (AAI).

Since during the last two decades a large part of investments were realized with participation of European Union funds, the time range of evaluation analyses is determined by the programming periods. In Polish conditions these are first of all the 2007-2013 period (with the possibility of settling the projects until 2015) and the presently running period of 2014-2020 (2023). In the former case, ex post evaluation of transport investments is possible, and in the latter - mainly the ex ante one. Ex ante evaluation is conditional on possessing possibly confirmed information on the planned actions (together with their scale, exact location and completion time). Investment plans undergo changes, adapting themselves to political cycles and financial capacity of the state. Nevertheless, due to the long and complicated process of preparing the individual projects, corrections radically changing the target layouts of transport networks are rare. This is why ex ante evaluation is valuable as a significant point of reference even if the whole investment process is slowed down.

In this paper we are focusing on the air transport, which means in this case AAI (Air Accessibility Indicator). The results are presented for 2007 and 2023 and the changes of the indicator are shown in the years of 2007-2013. The paper ends with conclusions and recommendations and bibliography.

This paper is based on the result of analyzes carried out in the framework of the project "Mobility-accessibility feedback loop. Theoretical considerations vs. Polish spatial reality (MA-trix)". The project was financed by funds of the National Science Centre on the basis of the decision UMO-2016/21/B/HS4/01578

\section{Methodological assumptions of the AAI indicator}

Accessibility examination methods used in the study. The starting point for deliberations on the methodological assumptions of AAI should be a brief review of methods for examining accessibility (Komornicki et al. 2010; Rosik 2012). As of today, there is no, and probably will never be, a single definition of accessibility universal and obligatory for all researchers. The multidimensional character of accessibility implies the possibility of studying this phenomenon using many differentiated methods (Rosik 2012). However, in most studies on that problem area a certain consensus prevails that allows for singling out a few most important types of methods (Geurs \& Ritsema van Eck 2001; Spiekermann et al. 2013) including: infrastructure-based accessibility measure - accessibility estimated using the indicators of infrastructural equipment of a given area, e.g. quantity and quality of linear and spot facilities of transport infrastructure; distance-based accessibility measure - Euclidean distance, actual physical distance (e.g. road distance), time distance (travel time) or economic distance (travel cost) between the origin and destination of the journey or a collection of destinations; cumulative accessibility (isochronic), and in the context of travel time utilization also as temporal accessibility (Komornicki et al. 2010); accessibility is measured by estimating the set of destinations accessible e.g. within a specified travel time, at a specified travel cost or effort; potential accessibility - accessibility measured based on the assumption that destination attractiveness decreases with increasing distance, travel time or cost, since the traffic participant is more willing to travel shorter than 
longer distances; the character of destination attractiveness decrease along with the lengthening distance is shown by the so-called distance decay function; person-based accessibility - taking into consideration the individual preferences of traffic participants.

Potential accessibility is the most frequently encountered approach in studying transport accessibility (Rosik 2012), especially in case of evaluating changes following from the development of transport infrastructure resulting from the implementation of individual projects or investment programs (Komornicki et al. 2010; Komornicki et al. 2013; Rosik et al. 2012; Rosik et al. 2015, Michniak et al. 2015; Rosik \& Stępniak 2015; Stępniak \& Rosik 2016; Więckowski et al. 2014). The group of models termed "potential accessibility” includes variants of accessibility measured with potential indicators. The most important distinction of potential accessibility is that the destination attractiveness increases together with its size and decreases along with increasing Euclidean, time or economic distance. In this paper we use the potential accessibility formula presented below (Spiekermann et al. 2013, Hansen 1959):

$$
A_{i}=\sum_{j} f_{1}\left(M_{j}\right) f_{2}\left(c_{i j}\right)
$$

where:

$A_{i}$ - transport accessibility of commune, poviat, voivodeship $i$,

$M_{j}$ - masses, e.g. airport capacity $j$,

$c_{i j}$ - travel time by road from transport zone $i$ to airport $j$.

The analysis made use of the exponential function $f\left(c_{i j}\right)=\exp \left(-\beta t_{i j}\right)$, where the appropriate parameter was indicated as $\beta=0,023105$ (see Spiekermann et al. 2013; Stępniak \& Rosik 2013), which means that destination attractiveness decreases by half for travel time amounting to exactly 30 minutes, while for about 100 minutes the attractiveness reduces to ca. $10 \%$ (e.g. for passenger transport, when the destination is a city with 100 thou. inhabitants located within 30 minute travel time, its attractiveness decreases to 50 thou. inhabitants, while for 100 minute travel - to just 10 thou. inhabitants).

Destination attractiveness. The source of data concerning masses in the air transport is not the population or GDP, like in case of roads and railway, but airport capacity. From the dynamic viewpoint, air accessibility changes are affected by changes in airport capacity and improvements in vehicle access to airports using road transport. The railway connections, although important and successfully used in Poland and other countries, are not the subject of this study.

Speeds in road transport. The calculation of AAI used the speed model for road transport developed at IGSO PAS, which indirectly takes into account both regulations (speed limits, lower speed in a developed area) and travel conditions (population living in the $5 \mathrm{~km}$ buffer from the road section and landform features). The speed model in individual traffic is to a large extent (with small modifications) based on the speed model for a dozen or so road categories (Rosik 2012). The considerable level of detail in transport network databases and the "linking" of all commune locations to the network of national and voivodeship roads by adding to that network the most important sections of commune and poviat roads enabled calculation of the AAl indicator on the commune level.

Infrastructural investments in road transport. During the research work, we obtained support from a series of beneficiaries regarding the lists of investments in road and railway transport. In the road sector, analysis of investments on the national and voivodeship road network (and in 
exceptional cases on key poviat roads) was assumed. When completing the lists of investments (status as at July 2014), we cooperated with:

- General Director for National Roads and Motorways (GDDKiA) - information on investments on national roads (Dokument Implementacyjny) (The Implementation Document represented the ranking of road investments to be implemented in the financial perspective 2014-2025. In the end it did not gain validity (in autumn 2015, the authorities decided that by 2025 all expressways and motorways set forth in the Ordinance of 2004 on the target layout of those routes, as amended, would have been built). Nevertheless, the tenders announced in the new perspective (after 2014) concerned almost exclusively the routes set forth in the Implementation Document. It remained the list of best prepared investments, whose final implementation by 2023 is most probable),

- 16 Marshal's Offices - information on investments on voivodeship roads identified in the process of negotiating territorial contracts,

- 66 City Offices of cities with poviat rights - information on investments in cities with poviat rights. Each of beneficiaries was asked to provide the relevant data characterizing the investment. GDDKiA sent files with the exact courses of all planned investments, including location of the nodes. In addition, lists of investments on national roads were supplemented for motorway sections built by private concessionaries.

Infrastructural investments in air transport. For air transport, the list of investments was prepared based on generally available information on the implemented and planned infrastructural investments at airports and on the waterway network for inland navigation.

The total number of all implemented and planned investments including road transport entered in the database considerably exceeded one thousand. Network update in order to enter the investments into the model required the adjustment to the requirements of calculating AAI for a few thousand of network sections (each investment consisted of multiple network sections).

Air accessibility. Air accessibility was assumed to result on the one hand from the time of travel to all airports in the country, and on the other hand to depend on the airport capacity. All major investments carried out at airports and aimed at increasing the capacity of terminals were taken into consideration. Attractiveness of an airport was assumed to be analogous to its capacity.

Spatial scope. On each spatial level of the analysis below the national one, i.e. from the commune level through the voivodeship level up to the macro-region level, accessibility analysis is prepared based on all routes between an arbitrary pair of communes in Poland (matrix layout). The indicators obtained on the commune level are appropriately aggregated to the poviat, voivodeship and macro-region levels. The conducted verification enabled calculation of the AAI indicator as the net effect of implementation of various strategic documents, as well as of the individual (national and regional) Operational Programmes, macro-regional and regional strategies.

\section{Results of air indicator AAI}

The spatial distribution of air accessibility in Poland is determined by the location of two airports in Mazovia, i.e. the capacity of the Warsaw Okęcie airport (and, to a lesser degree, the new Warsaw Modlin aiport), as well as by the road system providing access to the most important airports. This means that the best accessibility is in the vicinity of the capital metropolis and in the A2 (from Poznań to Warsaw) and A4 (from Wrocław to Cracow) road belts, with a "peak" 
of accessibility between Katowice and Cracow (in 2015, airports in Pyrzowice and Balice already had the highest capacity after the airport in Warsaw). Furthermore, Pomerania was an "island" of better accessibility (Fig. 1).

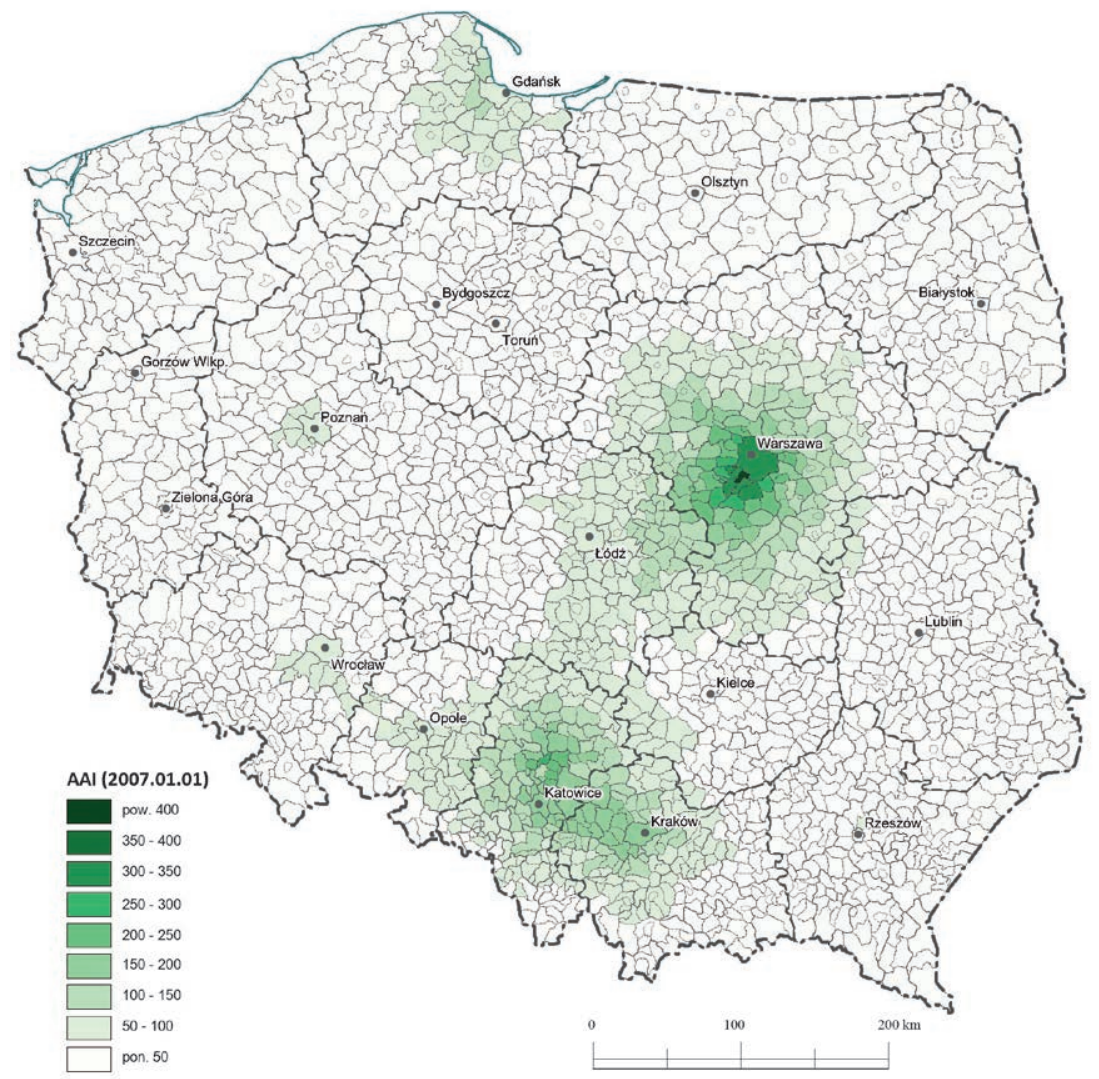

Figure 1. Air Accessibility Indicator AAI - in 2007

In 2007, there were no airports in Lublin and Modlin. The capacity of the largest airports in the country was at least twice, and in certain cases several times, lower in 2007 than at the end of the programming period 2007-2013. The total estimated capacity of airports in Poland grew in the programming period 2007-2013 more than twice (from about $25 \mathrm{M}$ passengers annually to about 58 M). Taking into account the aviation market dynamics in Poland and the total number of passengers serviced in 2014 - about $27 \mathrm{M}$ - points at the conclusion that investments completed by 2015 meet the demands up to around 2030. Vehicle access to airports in 2007 was also hindered by the lack of motorways on most access routes. Due to numerous infrastructural investments, both at the airports themselves and on access routes to the airports, airport accessibility increased significantly in the programming period 2007-2013. In percentage terms, Eastern Poland benefited the most (over threefold AAI indicator increase), including in particular the Lubelskie and Podlaskie Voivodeships, primarily as a result of the launch of new airports in Lublin and Modlin. A significant beneficiary was also the Kuyavian-Pomeranian Voivodeship, mainly thanks to the completion of the northern 
section of the A1 motorway, but also as a result of increasing the capacity of the Bydgoszcz airport (over fourfold increase in the AAI indicator value).

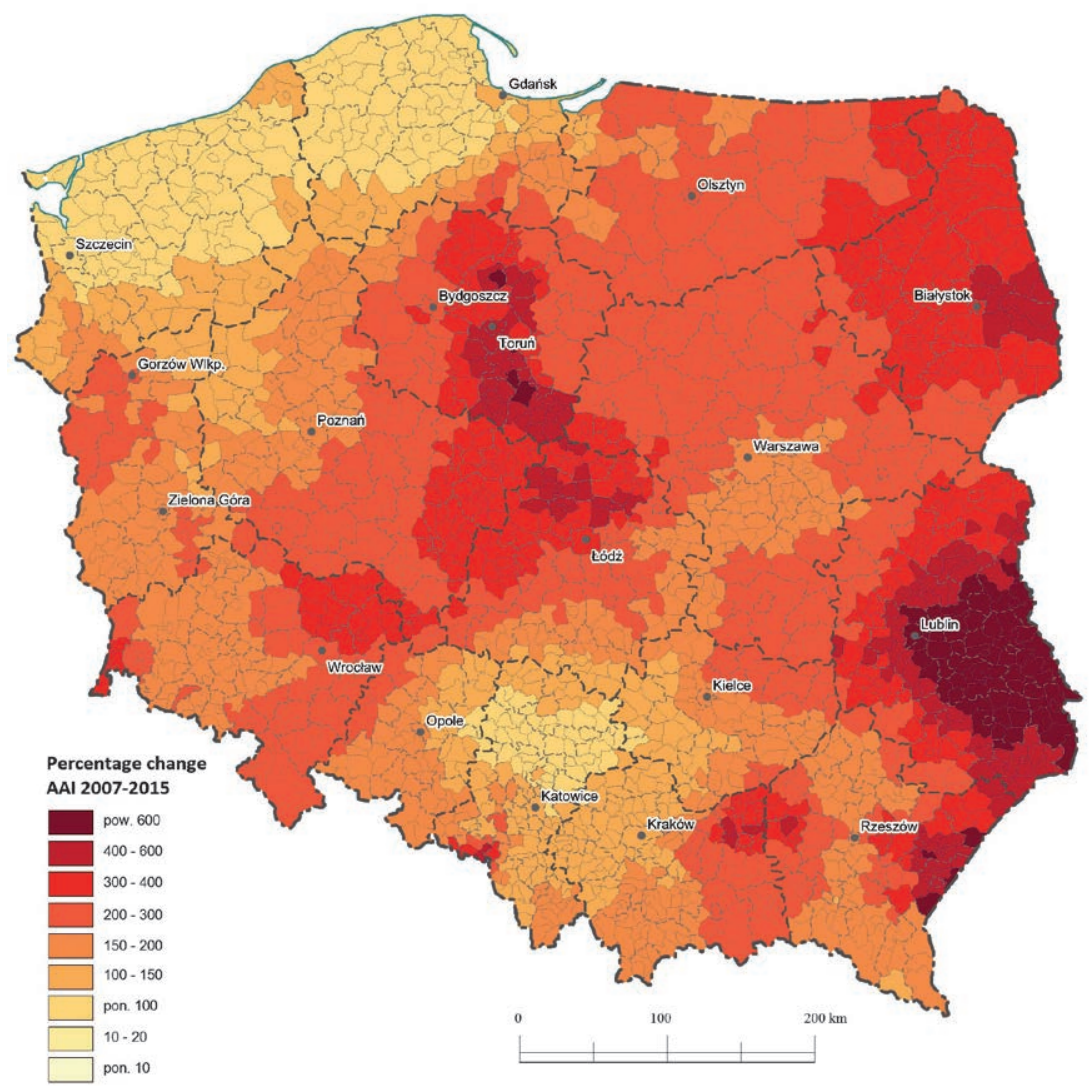

Figure 2. Percentage change in the Air Accessibility Indicator AAI in 2007-2015

The area where the indicator changed only slightly was Central Pomerania. It is an area geographically distant from the closest airports and, at the same time, deprived of large road investments in 2007-2015. From the voivodeship viewpoint, air accessibility improved the most in the Masovian and then the Łódź Voivodeships. Large increases occurred in the Lesser Poland and Silesian Voivodeships, while the Western Pomeranian Voivodeship definitely benefited the least. No investments improving airport capacity co-financed from European Union funds were provided for implementation in the programming period 2014-2020. Air accessibility changes in 2013-2020 stem from the ending investments planned in the programming period 2007-2013 and from a planned investment most likely executed from other sources, i.e. the necessary expansion of the Modlin airport. A significant improvement in air accessibility in many areas will occur mainly as a result of road investments. In view of the clearly shortening travel time to the already operating airports, the construction of further airports may give rise to substantial doubts.

In 2023, the significant improvement air accessibility stemmed from a series of investments implemented in airports (primarily in the programming period 2007-2014), as well as the improvement 
in access to these airport as a result of road investments on motorways and expressways. Thus, in 2023, the two poles of best accessibility: Mazovia and Cracow-Upper Silesia merge together, creating an area of perfect air accessibility. On the other hand, the West Pomeranian Voivodeship is characterised by the worst air accessibility in the country (the proximity of airports outside the territory of Poland was not taken into account) (Fig. 3).

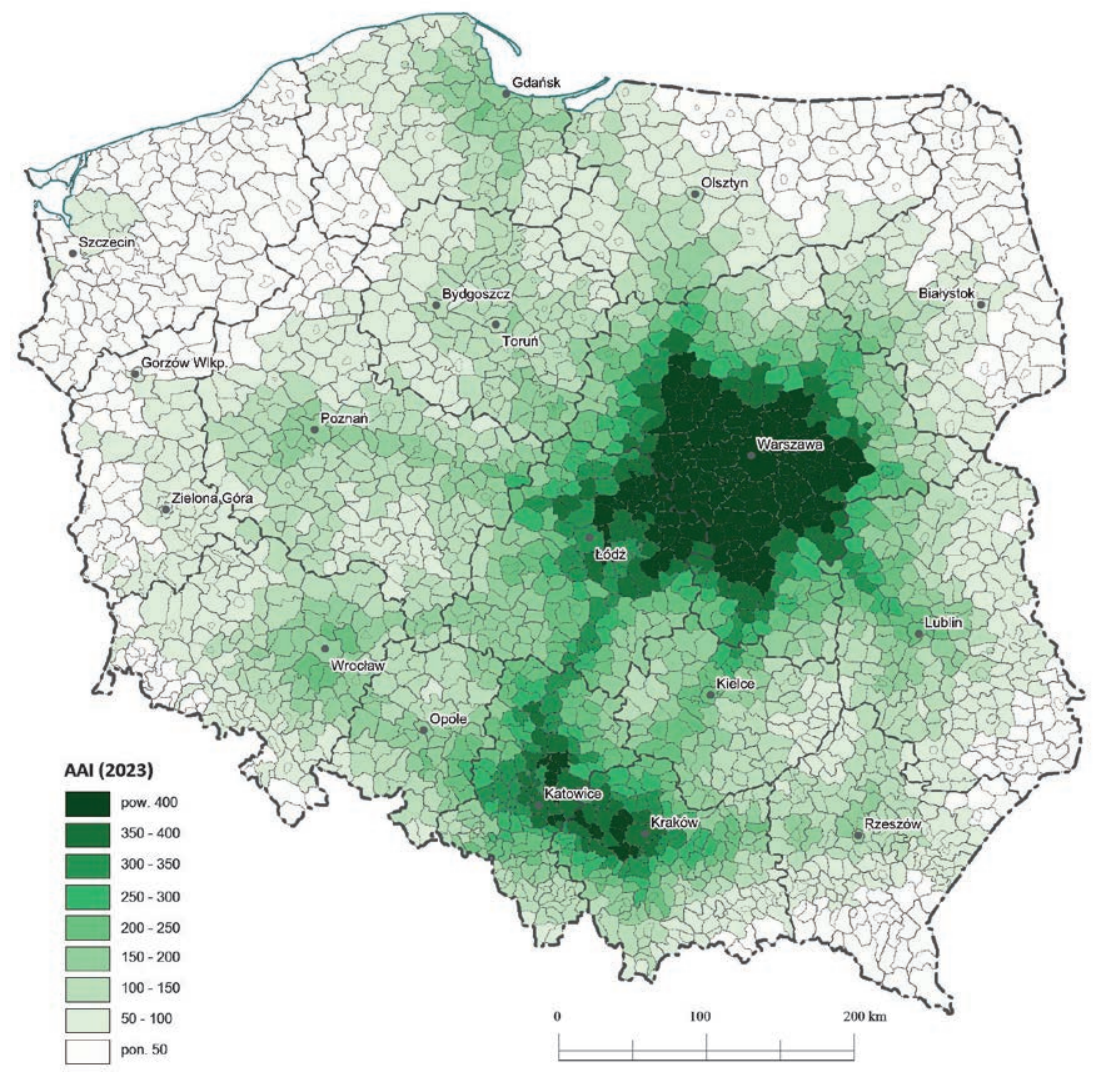

Figure 3. Air Accessibility Indicator AAI - in 2023

The conducted study confirms the thesis that accessibility improvement in air transport may be achieved both through erection and modernisation of airport infrastructure (new facilities, capacity increase) and by developing land transport. This is why large AAl increases may occur in areas distant from airports. It is a premise for critical reflection on the purposefulness of undertaking certain new investments in the form of erecting airports. Their possible creation has to be evaluated taking into account activities in other transport modes. This in particular applies to investments relatively not distant from the Mazovian system of airports. It seems that an argument for erecting new structures may be the lack of capacity of the already existing airports, not the rapidly changing temporal distance for travelling to them. 


\section{Application potential of AAI. Accessibility monitoring (2004-2023)}

The accessibility indicator provides many educational opportunities, also as part of a constant monitoring system, which is especially beneficial from the viewpoint of the operation of such bases as STRATEG (system created by Central Statistical Office of Poland for the purposes of programming and monitoring development policies). As part of continuous monitoring of the accessibility phenomenon, biannual images of changes (basic measurement of accessibility monitoring) were presented both for accessibility dynamics (since 2004) and for changes in spatial differentiation in the studied period (Potential Accessibility Dispersion index-PAD). Research results were presented in the context of accessibility changes on the voivodeship level in relation to the weighted average of changes for the whole country. Accessibility data at the commune level, aggregated accordingly to the voivodeship and country level, was adopted as the starting point. The analysis was conducted for data as at the end of 2004, 2006, 2008, 2010, 2012, 2015 and 2023. For 2015, investments ending in 2016 but implemented as part of the programming period 2007-2013 were included as well. The choice of those years followed from the following premises. Firstly, the investment intensification processes and, consequently, the acceleration of accessibility changes, were taking place from the very beginning of Poland's entry into the European Union - because of that, 2004 was chosen as the starting year. Secondly, the primary stipulated interval of accessibility analysis should be a two-year period - hence the two-year gaps between individual observations included for 2004-2012. Thirdly, the inability to conduct analysis as at the end of 2016, with the concurrent need to present the most reliable and up-to-date data as at the end of 2015, has resulted in not listing the data as at the end of 2014 in favour of including the calculated 2015 plus variant. Results were shown in the form of charts illustrating the dynamics of changes in the respective indicators on the voivodeship level. Focus was placed on general conclusions related to accessibility the dynamics at the mode level.

In air transport (AAI), there is a strong dominance of Mazovia as the best accessible region of the country. This dominance grew even more as a result of commissioning the second airport in this region, in Modlin. Second place, as a result of improving road accessibility to airports (primarily to the Warsaw Chopin Airport, through the southern section of the Warsaw express ring road and the A2 motorway) is occupied by the Łódź Voivodeship (mainly thanks to the improvement in the road accessibility to airports in the neighbouring voivodeships) and it is closely followed by the Lesser Poland and Silesian Voivodeships. Other voivodeships remain below the country average for air accessibility. Increase in air accessibility until 2023 will be lower than in 2012-2015, when an unprecedented "flood" of infrastructural investments increasing the capacity of airports occurred (Fig. 4). 


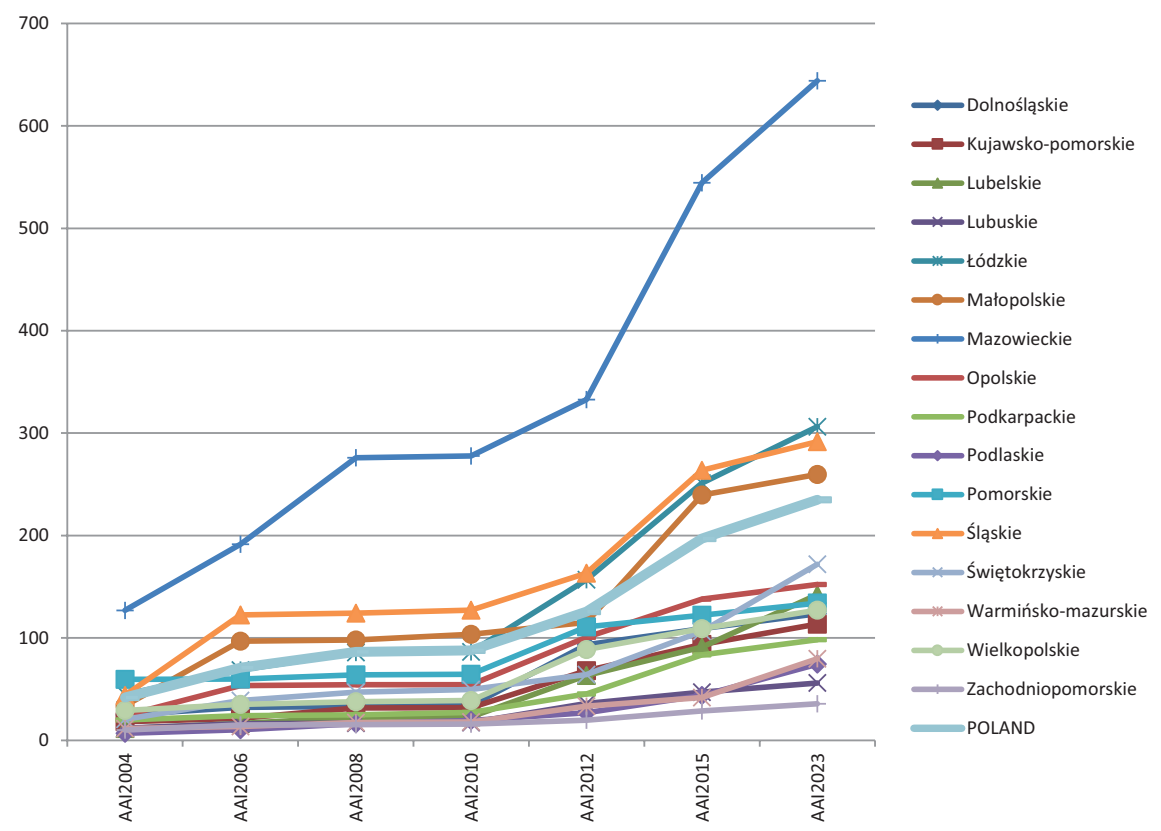

Figure 4. Dynamics of the AAl indicator

Accessibility differences in 2004-2023. PAD Potential Accessibility Dispersion index. The analysis of the accessibility phenomenon dynamics is complemented by the research on its differences. For this purpose, the PAD (Potential Accessibility Dispersion) index was used, which is created through a ratio of the accessibility indicator standard deviation to the average weighted by the population indicator value on the commune level. The higher the indicator value, the higher the accessibility differences and the lower the indicator, the lower the differences. In the dynamic presentation, a decrease of spatial polarisation occurs as a result of the indicator value decreasing in time, while an increase in polarisation - as a result of the indicator increasing. A positive phenomenon, from the point of view of the cohesion policy, is therefore a decrease of the indicator value in the years of 2008-2012 and some kind of stabilization till 2023 (Tab. 1).

Table 1. Values of the PAD Potential Accessibility Dispersion index

\begin{tabular}{|l|l|l|l|l|l|l|l|}
\hline & $\mathbf{2 0 0 4}$ & $\mathbf{2 0 0 6}$ & $\mathbf{2 0 0 8}$ & $\mathbf{2 0 1 0}$ & $\mathbf{2 0 1 2}$ & $\mathbf{2 0 1 5}$ & $\mathbf{2 0 2 3}$ \\
\hline AAI & 0.656 & 0.670 & 0.716 & 0.711 & 0.589 & 0.632 & 0.633 \\
\hline
\end{tabular}

\section{Conclusions and recommendations}

Poland is slowly entering the development phase where some regions become saturated with modern transport infrastructure (road and air infrastructure in particular). This applies primarily to the western and southern parts of the country. In these areas, successive road investments give noticeably lesser effects in respect of accessibility improvement, although links between the existing higher class roads closing the network completely may become key after 2023. Due to the above factors, the distribution of planned accessibility changes becomes a better premise for making 
further investment decisions than it was in the previous financial perspective (the generally weak accessibility in the entire country justified any activities).

The capacity of the largest airports in the country was at least two times, and in certain cases a few times lower in 2007 than by the end of the programming period 2007-2013. Vehicle access to airports was also hindered by the lack of motorways on most access routes. The spatial distribution of air accessibility in Poland is, also in 2015, determined by the location of two airports in Mazovia, i.e. the capacity of Warsaw Okęcie airport (and, to a lesser degree, the new Warsaw Modlin aiport), as well as by the road system providing access to the most important airports. This means that the best accessibility is in the vicinity of the capital metropolis and in the A2 (from Poznan to Warsaw) and A4 (from Wrocław to Cracow) road belts, with a "peak" of accessibility between Katowice and Cracow.

By percentage, Eastern Poland benefited the most from air investments (over threefold AAI indicator increase), including in particular the Lublin and Podlaskie Voivodeships, primarily as a result of opening new airports in Lublin and Modlin.

In conclusion, the conducted research confirms the thesis that improvement of accessibility in air transport may be achieved both by erecting or modernising airport infrastructure (new structures, capacity increase) and by developing land transport. It is a premise for a critical reflection on the purposefulness of undertaking certain new investments in the form of erecting airports. Further development of airports (aside of investments planned in certain airports, e.g. in Warsaw or Modlin) is hard to justify in light of the high capacity parameters stemming from investments implemented in the programming period 2007-2014, and also due to the improvement in access to the existing airports, both via road and railway transport. Moreover, the unexpected decisions (one big national airport or group of regional airports) can change the whole map of transport infrastructure in Poland (together with transport accessibility to airports).

\section{References}

Geurs K. T., Ritsema van Eck, 2001. Accessibility Measures: Review and Applications. RIVM report 408505 006, Bilthoven: National Institute of Public Health and the Environment.

Hansen W. G., 1959. How Accessibility Shapes Land-use. Journal of the American Institute of Planners, vol. 25, pp. $73-76$.

Komornicki T., Śleszyński P., 2011. Changing accessibility of Polish airports on the course of demographic and economic demand. Geographia Polonica, vol 84, iss. 2, pp. 47-63.

Komornicki T., Rosik P., Śleszyński P., Solon J., Wiśniewski R., Stępniak M., Czapiewski K., Goliszek S., 2013. Impact of the construction of motorways and expressways on socio-economic and territorial development of Poland. Poland: Ministry of Regional Development.

Komornicki T., Śleszyński P., Rosik P., Pomianowski W., 2010. Dostępność przestrzenna jako przesłanka kształtowania polskiej polityki transportowej. CSERP PAS bulletin, Warsaw, iss. 241, 165 pp.

Kopeć K., 2004. Port lotniczy w Gdańsku - jego funkcjonowanie i perspektywy rozwoju. Prace Komisji Geografii Komunikacji PTG, vol. 16, pp. 115-130.

Michniak D., Więckowski M., Stępniak M., Rosik P., 2015. The impact of selected planned motorways and expressways on the potential accessibility of the Polish-Slovak borderland with respect to tourism development. Moravian Geographical Reports, 1. 
Pijet-Migoń E., 2007. Lotnicze przewozy pasażerskie w Polsce po akcesji do Unii Europejskiej - wymiar przestrzenny. Prace Komisji Geografii Komunikacji PTG, vol. 14, pp. 107-122.

Rosik P., 2012. Dostępność lq̨dowa przestrzeni Polski w wymiarze europejskim. Prace Geograficzne, Warsaw: IGiPZ PAN, iss. 233, 307 pp.

Rosik P., Stępniak M., 2015. Monitoring of changes in road potential accessibility at municipality level in Poland, 1995-2015. Geographia Polonica, vol. 88 (4), pp. 607-620.

Rosik P., Stępniak M., Komornicki T., 2015. The decade of the big push to roads in Poland: Impact on improvement in accessibility and territorial cohesion from a policy perspective. Transport Policy, vol. 37, pp. 134-146.

Rosik P., Stępniak M., Komornicki T., Pomianowski W., 2012. Monitoring spójności terytorialnej gmin w skali krajowej i międzynarodowej w latach 1995-2030. Raport końcowy, IGiPZ PAN (non-printed material prepared as part of the $5^{\text {th }}$ MRR dotation competition).

Spiekermann K., Wegener M., Květoň V., Marada M., Schürmann C., Biosca O., Ulied Segui A., Antikainen H., Kotavaara O., Rusanen J., Bielańska D., Fiorello D., Komornicki T., Rosik P., Stepniak M., 2013. TRACC Transport Accessibility at Regional/Local Scale and Patterns in Europe. Draft Final Report. ESPON Applied Research.

Stępniak M., Rosik P., 2016. From improvement in accessibility to the impact on territorial cohesion: the spatial approach. Journal of Transport and Land Use, vol. 9 (3), pp. 1-13.

Stępniak M., Rosik P., 2013. Accessibility improvement, territorial cohesion and spillovers: a multidimensional evaluation of two motorway sections in Poland. Journal of Transport Geography, vol. 31, pp. 154-163.

Taylor Z., Ciechański A., 2016. Transport means and organized tourism: empirical evidence from Poland. Geographia Polonica, vol. 89, iss. 4, pp. 485-504.

Trzepacz P., 2007. Kierunki i uwarunkowania rozwoju sieci portów lotniczych Polski. Prace Komisji Geografii Komunikacji PTG, vol. 14, pp. 123-147.

Więckowski M., Michniak D., Bednarek-Szczepańska M., Chrenka B., Ira V., Komornicki T., Rosik P., Stępniak M., Szekely V., Śleszyński P., Świątek D., Wiśniewski R., 2014. Road accessibility to tourist destinations of the Polish-Slovak borderland: 2010-2030 prediction and planning. Geographia Polonica, vol. 87 iss. 1, pp. 5-26.

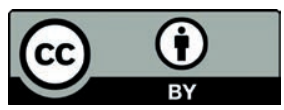




\section{INFORMATION FOR AUTHORS}

Manuscripts, in the English language, should be submitted to the Secretary of EUROPA XXI (Institute of Geography and Spatial Organization, Polish Academy of Sciences, Twarda 51/55 00-818 Warsaw, Poland; tkomorn@twarda.pan.pl).

The manuscripts should be arranged in the following order. First sheet: title, full name of author(s), affiliation, full postal address, e-mail address. Second sheet: abstract of no more than 100 words, key words (3-10) at the end of the abstract. Subsequent sheets: the main text of 5,000-8,000 words. The main text may be organized in sections under appropriate headings without numerals.

REFERENCES should be printed in alphabetical sequence at the end of the text. Examples:

Articles from journals:

Törnqvist G., 2004. Creativity in time and space. Geografiska Annaler. Series B. Human Geography, vol. 86 , no. 4 , pp. 227-244.

Books:

Pacione M., 2001. Urban geography. A global perspective. London-New York: Routledge.

Chapters from books:

Haworth E.Y., Hurley M.A ., 1984. Comparison of the stelligeroid taxa of the centric diatom genus Cyclotella. [in:] M. Ricard (ed.), Proceedings of the 8th International Diatom Symposium, Paris-Koenigstein: Koeltz Scientific Books, pp. 43-58.

Maps:

Prest V.K., Grant D.G., Rampton V.N., 1968. Glacial Map of Canada. Map 1253A , 1:5000000, Ottawa: Geological Survey of Canada.

Unpublished documents (theses, 'grey literature'):

Kohno A ., Stubblefield A ., Rubin A.D., Wallach D.S., 2004. Analysis of an electronic voting systems. Johns Hopkins University Information Security, 23 pp. [typescript].

Electronic and Internet documents or websites:

CIT, 2012. NASA Jet Propulsion Laboratory. California Institute of Technology, http://www.jpl.nasa. gov/ [1 December 2011]. 
References should be indicated in the text by listing, in parenthesis, the author's name followed by the data of publication, e.g. (Haeberli 1975; Pacione 2001) or (Haworth \& Hurley 1984) or (Boudevillain et al. 2009) if there are more than two authors (Note: all the author s should be listed in the references).

FOOTNOTES and NOTES should be referred to by superscript letters.

ILLUSTRATIONS should be supplied in one of the following formats:

- photographs: JPG, TIFF, EPS or PSD,

- maps, figures and diagrams should be presented as vector files in Al (Adobe Illustrator) or one of the format mentioned above.

Please ensure that the resolution is not lower than $300 \mathrm{dpi}$ and the lines are a minimum of 0.3 points thick. Please also supply printouts of illustrations that are to be presented, in black and white or in colours, in relation to the required final appearance in print.

TABLES should be printed on separate sheets and numbered sequentially with Arabic numerals (e.g. Table 1). Each table should be provided with a clear descriptive caption at the top and informative column headings.

EQUATIONS and SYMBOLS used in mathematical formulae must be clearly explained. Axes on graphs should be described clearly. Units and abbreviations used by authors should conform to the International List.

MEASUREMENTS should be given in metric units.

ACCEPTED MANUSCRIPTS.

Articles accepted for publication in EUROPA XXI are not honoured financially. Authors of accepted articles will receive one copy of the journal free of charge.

Authors are responsible for indicating copyright as w ell as permission from the copyright holder to reproduce any texts, tables or illustrations for which copyright exists. 


\section{Territorial capital - different perspectives}

- Balázs István Tóth

Territorial capital a fuzzy policy-driven concept: context, issues, and perspectives

Michał Konopski

Territorial uncertainty of Podlasie region. Regional identity vs. administrative division

- Tomasz Józefowski, Andrzej Młodak Special economic zones in the context of regional development

- Sławomir Goliszek

Space-time variation of accessibility to jobs with used by public transport - case study in Szczecin

- Piotr Rosik, Tomasz Komornicki, Sławomir Goliszek, Marcin Stępniak, Wojciech Pomianowski

Trends in potential accessibility to airports in Poland (AAl indicator) 